\title{
WATER QUALITY ANALYSIS OF BHISHMA LAKE AT GADAG CITY
}

\author{
Anupama Kuradagi ${ }^{1}$, R B. Gadag ${ }^{2}$ \\ ${ }^{I}$ Anupama Kuradagi, Student, Department of Civil Engg, KLE's Dr.MSSCET, Belagavi, Karnataka, India \\ ${ }^{2} R$ B. Gadag, Associate Professor, Department of Civil Engg, KLE's Dr.MSSCET, Belagavi, Karnataka, India
}

\begin{abstract}
The water bodies are facing a severe threat of pollution all over the world. Eutrophication in lakes is widespread all over the world and the severity is increasing especially in the developing countries like India. The main objective is to study the effects of pollution of water quality in Bhishma lake due to rapid urbanization and to identify the sources of pollution in lake. The samples were collected from January to April and bi-monthly tests were carried out. The physico-chemical characteristics of water samples like pH, turbidity, alkalinity, total hardness, total dissolved solids, nitrate, phosphate, chloride, potassium, sodium, dissolved oxygen, $B O D$ were analyzed in order to determine the level of contaminants present in lake water and its possible mitigation measures. Water qualities such as pH, Total Dissolved solids (TDS), turbidity, alkalinity, total hardness, chloride, sodium, nitrate, phosphate, potassium, Dissolved Oxygen (DO) and Biochemical Oxygen Demand (BOD), Chemical Oxygen Demand (COD) were determined for water samples collected from five stations in lake. The analysis of lake water parameters showed that the total hardness, turbidity, total dissolved solids and alkalinity values exceeding the desirable limit and due to presence of organic and inorganic pollutants Dissolved Oxygen (DO) has reduced, Biochemical Oxygen Demand (BOD) and Chemical Oxygen Demand (COD) has increased which shows the poor quality of water and is not suitable for human consumption these values have been graphically plotted.
\end{abstract}

Keywords: Lake Water Quality analysis, BOD, COD.

\section{INTRODUCTION}

Water is a primary source of life and sustains all human activities such as domestic needs, agriculture, industries etc., the allocation and management of water resource is becoming a difficult task due to increasing demands, decreasing supply and diminishing quality. This calls for judicious use of water resources. ${ }^{[1]}$

The use of water by man, plants and animals is universal, without it there can be no life. Every living thing requires water. Man and animal not only consume water but they also consume vegetation, for their food. Vegetation in turn cannot grow without water. The use of water is increasing rapidly with growing population. Already there is an acute shortage of both surface and underground water in many parts of the country. Careless pollution and contamination of the streams, lakes, reservoirs, wells and other underground water sources has greatly impaired the quality of available water. ${ }^{[1]}$

\section{2: Water Pollution.}

Water pollution is the contamination of the water body like lake, pond, river and ocean. Water pollution occurs when pollutants directly or indirectly enters in to the water bodies without proper treatment. ${ }^{[2]}$

\section{3: Classification of Sources Of Pollution.}

The sources of pollution may be classified into two parts. ${ }^{[2]}$

$>$ Point source.

$>$ Non point source.

$>$ Point sources: A point source is a stationary location or fixed facility from which pollutants are discharged or emitted or any single, identifiable discharge point of pollution such as a pipe or ditch. ${ }^{[2]}$

$>$ Non-point sources : The term non-point source is used to identify source of pollution that are diffuse and do not have a point of origin or that are not introduced into a receiving stream from a standard outlet. ${ }^{[2]}$

\section{4: Sources of Pollution In Lakes.}

$>$ It includes land use from agriculture, urban and urban development and other uses which contribute to pollution. Untreated domestic waste discharge from the cities also contributes to the pollution of lakes. ${ }^{[3]}$

$>$ Daily human activities like vehicles deposit oil on to roads, driveway and parking lots, flowing water picks up fertilizers applied to lawns and crops, pet and livestock waste which contains bacteria and virus. ${ }^{[3]}$

\section{5: Eutrophication.}

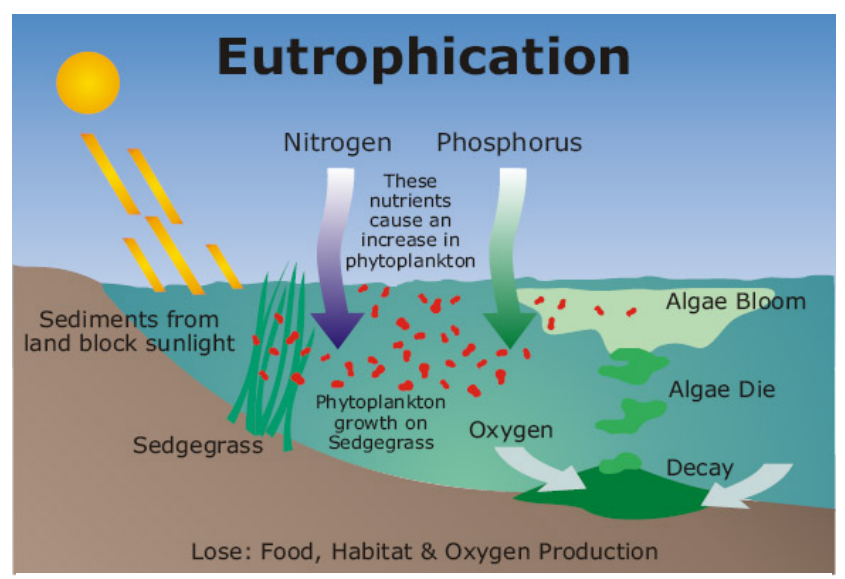

Fig 1.1: Typical representation of causes of eutrophication in lake. ${ }^{[5]}$ 
Lakes are defined by stagnant water surrounded by land. Quality and quantity of water does not only shows difference in the stream flow regime but also damages ecosystem. physical, chemical and biological parameters show the hydrologic status of water which shows quality and quantity of lakes. Light, wind, water and temperature, etc., classified under physical parameters. The chemical inputs include minerals, gas, oxygen and other metals. ${ }^{[5]}$

$>$ Eutrophication is a process taking place by enrichment of water by nutrients such as nitrogen and phosphorous. Eutrophication is the major problem faced by the surface water bodies that affects the quality of water. It damages fresh water and causes algal blooms, fish kills because of depletion of DO and effects other aquatic species. Domestic sewage include large quantity of phosphorus and nitrogen which effects lake water. Agriculture runoff also damages quality of lake water as it contains pesticides and fertilizers. ${ }^{[6,7]}$

Eutrophication is the major problem faced by developed and developing countries. Nutrients in the lakes usually come from point source e.g. municipal and industrial wastes and non-point source, e.g. agriculture run off. ${ }^{[7]}$

Lakes are classified as oligotrophic, eutrophic and mesotrophic depending on the nutrients present in the water bodies. Climate, vegetation, inflow and topography also effects lake water. ${ }^{[7]}$

\section{Objectives of the study}

$\checkmark$ To study the effects of point and non point pollution sources on water quality of Bhishma lake in Gadag city due to rapid urbanization.

$\checkmark \quad$ To identify the sources of pollution for Bhishma lake water and how much sewage is joining into the Bhishma lake with what characteristics?

$\checkmark$ To study the characteristics of raw sewage and physico - chemical characteristics of Bhishma lake water and check it's suitability for drinking purpose.

\section{MATERIALS AND METHODOLOGY}

\section{1:General}

Physico-chemical parameters for the water samples in Bhishma lake were analyzed during the study period. Methods and equipments used in the study are given in the table 3.1.

\begin{tabular}{|c|c|c|c|}
\hline $\begin{array}{l}\text { S1. } \\
\text { No. }\end{array}$ & Parameters & Principle & $\begin{array}{l}\text { Instrument / } \\
\text { Technique used }\end{array}$ \\
\hline 1 & $\mathrm{pH}$ & Electrometry & pH meter MK VI, Systronics,Sr.No-9872 \\
\hline 2 & Total Dissolved Solids & Ionometry & Conductivity meter/Ionometer 307,Systronics,Sr.No-373 \\
\hline 3 & Alkalinity & Titrimetric method & Titration, Volumetric glassware \\
\hline 4 & Total Hardness & EDTA Titrimetric method & Titration, Volumetric glassware \\
\hline 5 & Nitrate & $\begin{array}{l}\text { Phenol Di-sulphonic Acid } \\
\text { method }\end{array}$ & Digital Spectrophotometer \\
\hline 6 & Phosphate & Colorimetry method & Digital Spectrophotometer \\
\hline 7 & Sodium & Flame Photometry & Flame photometer,Systronics,type:128 \\
\hline 8 & Potassium & Flame Photometry & Flame photometer,Systronics,type: 128 \\
\hline 9 & Chloride & Argentometric method & Titration, Volumetric glassware \\
\hline 10 & Turbidity & Nephelometry method & $\begin{array}{l}\text { Nephlometer, } \\
\text { Elico 22A,Sr.No-0065 }\end{array}$ \\
\hline 11 & Dissolved Oxygen & Azide modification method & Volumetric glassware. \\
\hline 12 & $\begin{array}{ll}\text { Biochemical } & \text { Oxygen } \\
\text { Demand } & \end{array}$ & Dilution method & BOD incubator, BOD bottles \& titration apparatus. \\
\hline 13 & $\begin{array}{l}\text { Chemical Oxygen } \\
\text { Demand }\end{array}$ & Open Reflux method & COD digester. \\
\hline 14 & Suspended Solids & Gravimetric method & Suction apparatus, desicator. \\
\hline
\end{tabular}




\section{2: Characteristics of Sewage}

Table 3.2: Standards for discharging effluents in surface water. ${ }^{[19]}$

\begin{tabular}{|c|c|c|}
\hline $\begin{array}{l}\text { SI. } \\
\text { No }\end{array}$ & Characteristics & $\begin{array}{l}\text { Tolerance } \\
\text { limit }\end{array}$ \\
\hline 1. & $\begin{array}{l}\text { Total suspended solids, } \mathrm{mg} / \mathrm{L} \text {, } \\
\text { max }\end{array}$ & 100 \\
\hline 2. & $\begin{array}{l}\text { Particles size of total suspended } \\
\text { solids. }\end{array}$ & $\begin{array}{l}\text { Shall pass IS } \\
\text { sieve } 850\end{array}$ \\
\hline 3. & $\mathrm{PH}$ & 5.5 to 9.0 \\
\hline 4. & Temperature & $\begin{array}{l}\text { Shall not } \\
\text { exceed } 40^{\circ} \mathrm{C} \text { in } \\
\text { any section of } \\
\text { the streams } \\
\text { within } 15 \mathrm{~m} \\
\text { downstream } \\
\text { from the } \\
\text { effluent outlet }\end{array}$ \\
\hline 5 . & Color \& Odor & $\begin{array}{l}\text { Should be } \\
\text { absent as far as } \\
\text { practicable. }\end{array}$ \\
\hline 6. & $\mathrm{COD}, \mathrm{mg} / \mathrm{L}, \max$ & 250 \\
\hline 7. & Oil \& grease, $\mathrm{mg} / \mathrm{L}, \max$ & 10 \\
\hline 8. & Phenolic compounds, mg/L max & 1.0 \\
\hline 9. & Cyanides (as CN), mg/L, max & 0.2 \\
\hline 10. & Sulphides (as S), mg/L, max & 2.0 \\
\hline 11. & $\begin{array}{l}\text { Radioactive materials } \\
\text { a. Alpha emitters } \mu \mathrm{c} / \mathrm{ml} \text {, max } \\
\text { b. Beta emitters } \mu \mathrm{c} / \mathrm{ml} \text {, max }\end{array}$ & $\begin{array}{l}10^{-7} \\
10^{-6}\end{array}$ \\
\hline 12. & Insecticides & Absent \\
\hline 13. & $\begin{array}{l}\text { Total residual chlorine, } \mathrm{mg} / \mathrm{L} \text {, } \\
\max \end{array}$ & 1.0 \\
\hline 14. & Fluorides (as F),mg/L, $\max$ & 2.0 \\
\hline 15. & Arsenic (as As),mg/L, max & 0.2 \\
\hline 16. & Cadmium (as Cd), mg/L, $\max$ & 2.0 \\
\hline 17. & $\begin{array}{l}\text { Hexavelent Chromium (as } \\
\left.\mathrm{Cr}^{+6}\right), \mathrm{mg} / \mathrm{L}, \max \end{array}$ & 0.1 \\
\hline 18. & Lead (as Pb), mg/L, max & 0.1 \\
\hline 19. & Copper (as Cu), mg/L, $\max$ & 3.0 \\
\hline 20. & Mercury (as $\mathrm{Hg}$ ), mg/, max & 0.01 \\
\hline 21. & Nickel (as Ni), mg/L, max & 3.0 \\
\hline 22. & Selenium (as Se), mg/L, max & 0.05 \\
\hline 23. & Zinc (as $\mathrm{Zn}$ ), $\mathrm{mg} / \mathrm{L}, \max$ & 5.0 \\
\hline 24. & Ammonical nitrogen, $\mathrm{mg} / \mathrm{L}, \max$ & 5.0 \\
\hline 25 . & $\begin{array}{l}\text { BOD for } 5 \text { days a } 20^{\circ} \mathrm{C}, \mathrm{mg} / \mathrm{L} \text {, } \\
\max \end{array}$ & 30 \\
\hline
\end{tabular}

\section{3: Sampling Technique}

\subsection{1: Grab Sampling}

A grab sample is one discrete sample where the sample is collected at once and can only represent the conditions at a particular time. It can be done manually by dipping the container directly into the water to be sampled or by using a pump. ${ }^{[21]}$

\subsection{2: Collection of Sample}

Samples were collected and stored in bottles. Diluted hydrochloric acid or detergents were used for cleaning the bottles. Once the bottles were cleaned thoroughly rinsed with the reagent water and sealed properly. All samples were properly labeled with time of sampling and date of sampling and the source. The samples were tested in laboratory within the 24 hours. If the time exceeds 24 hours the samples have to be preserved at $4^{0} \mathrm{C}$ and the analysis should be done within 48 hours. ${ }^{[21]}$

The samples from the lake were collected from January 2015 to April 2015. Bi-monthly samples were collected periodically during morning hours between 8 am to $10 \mathrm{am}$. The physico-chemical parameters such as turbidity, $\mathrm{pH}, \mathrm{DO}$, TDS, BOD, nitrate, phosphate, potassium, sodium, chloride, hardness, suspended solids, COD \& alkalinity were analyzed in both, Environmental laboratory, Department of Civil Engineering, KLE Dr. MSSCET Belgavi and Krishi Vigyana Kendra, Hulkoti according to APHA AWWA standard methods. ${ }^{[21]}$

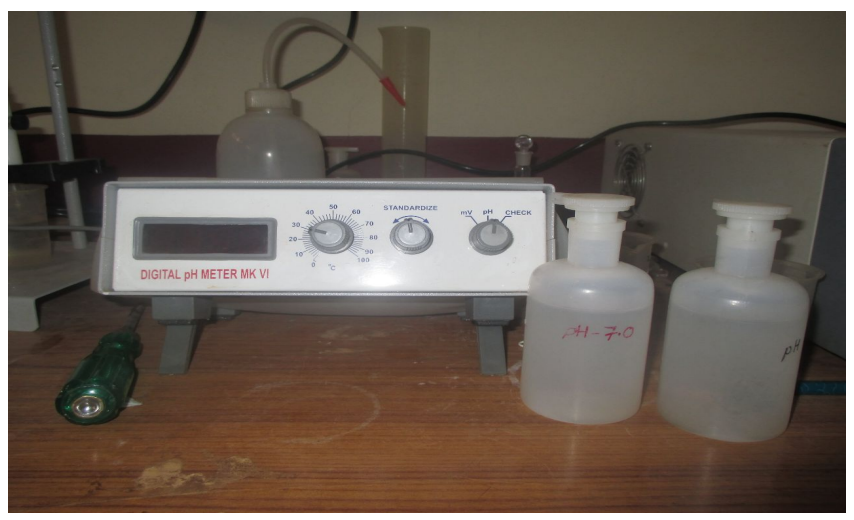

\section{RESULTS AND DISCUSSION}

\section{1: Characteristics of Raw Sewage Joining Into}

Bhishma Lake.

\begin{tabular}{|l|l|l|l|l|}
\hline Parameters & $\begin{array}{l}\text { Raw sewage } \\
\text { January-20 }\end{array}$ & $\begin{array}{l}\text { Raw sewage } \\
\text { February-20 }\end{array}$ & $\begin{array}{l}\text { Raw sewage } \\
\text { Marh-20 }\end{array}$ & $\begin{array}{l}\text { Raw sewage } \\
\text { April-20 }\end{array}$ \\
\hline pH & 6.20 & 6.30 & 6.50 & 6.70 \\
\hline Chloride & $55.20 \mathrm{mg} / \mathrm{L}$ & $58.32 \mathrm{mg} / \mathrm{L}$ & $64.20 \mathrm{mg} / \mathrm{L}$ & $68.12 \mathrm{mg} / \mathrm{L}$ \\
\hline Total Dissolved Solids & $580.10 \mathrm{mg} / \mathrm{L}$ & $600.23 \mathrm{mg} / \mathrm{L}$ & $630.11 \mathrm{mg} / \mathrm{L}$ & $648.18 \mathrm{mg} / \mathrm{L}$ \\
\hline Dissolved Oxygen & 0.00 & 0.00 & 0.00 & 0.00 \\
\hline Biochemical Oxygen Demand & $208.32 \mathrm{mg} / \mathrm{L}$ & $220.12 \mathrm{mg} / \mathrm{L}$ & $232.80 \mathrm{mg} / \mathrm{L}$ & $238.72 \mathrm{mg} / \mathrm{L}$ \\
\hline Chemical Oxygen Demand & $335.12 \mathrm{mg} / \mathrm{L}$ & $355.16 \mathrm{mg} / \mathrm{L}$ & $372.12 \mathrm{mg} / \mathrm{L}$ & $392.20 \mathrm{mg} / \mathrm{L}$ \\
\hline Nitrate & $54.17 \mathrm{mg} / \mathrm{L}$ & $56.21 \mathrm{mg} / \mathrm{L}$ & $57.23 \mathrm{mg} / \mathrm{L}$ & $58.11 \mathrm{mg} / \mathrm{L}$ \\
\hline Phosphate & $6.32 \mathrm{mg} / \mathrm{L}$ & $6.29 \mathrm{mg} / \mathrm{L}$ & $6.30 \mathrm{mg} / \mathrm{L}$ & $6.33 \mathrm{mg} / \mathrm{L}$ \\
\hline Suspended Solids & $192.23 \mathrm{mg} / \mathrm{L}$ & $222.35 \mathrm{mg} / \mathrm{L}$ & $243.14 \mathrm{mg} / \mathrm{L}$ & $273.21 \mathrm{mg} / \mathrm{L}$ \\
\hline
\end{tabular}


The raw sewage which is joining into Bhishma lake is dark grey in color with stinking smell and the temperature is $28^{0} \mathrm{C}$ which is measured with the help of thermometer.

Grab sampling was carried out monthly for four months from January 2015 to April 2015. Monthly once the raw sewage was collected in a bottle $30 \mathrm{~cm}$ from the surface and tested for the above parameters in the lab rotary.

\subsection{1:pH.}

The $\mathrm{pH}$ values analyzed for the water samples at sampling stations 1, 2, 3, 4 and 5 are given below.

Table 4.2: shows the $\mathrm{pH}$ values analyzed at five sampling stations for Bhishma lake, Jan 2015 to Apr 2015.

\begin{tabular}{|l|l|l|l|l|l|l|}
\hline Month & $\begin{array}{l}\text { Sampling } \\
\text { station-1 }\end{array}$ & $\begin{array}{l}\text { Sampling } \\
\text { station-2 }\end{array}$ & $\begin{array}{l}\text { Sampling } \\
\text { station-3 }\end{array}$ & $\begin{array}{l}\text { Sampling } \\
\text { station-4 }\end{array}$ & $\begin{array}{l}\text { Sampling } \\
\text { station-5 }\end{array}$ & BIS:10500-2012 \\
\hline Jan $27^{\text {th }}$ & 7.5 & 8.0 & 8.2 & 8.3 & 7.8 & 7.7 \\
\hline Feb $11^{\text {th }}$ & 7.7 & 8.1 & 8.0 & 8.1 & 7.6 & $6.5-8.5$ \\
\hline Feb $26^{\text {th }}$ & 7.4 & 8.2 & 7.9 & 8.0 & 7.9 \\
\hline Mar $13^{\text {th }}$ & 7.8 & 8.0 & 8.1 & 8.2 & 8.1 \\
\hline Mar $27^{\text {th }}$ & 7.6 & 7.9 & 8.2 & 8.0 & 8.0 \\
\hline Apr $11^{\text {th }}$ & 7.5 & 7.8 & 7.9 & 8.1 & 7.9 & 7.3 \\
\hline Apr $26^{\text {th }}$ & 7.8 & 8.3 & 8.3 & 8.3 & $\mathbf{8 . 0}$ & \\
\hline Mean pH & $\mathbf{7 . 5}$ & $\mathbf{8 . 0}$ & $\mathbf{8 . 0}$ & $\mathbf{8 . 0}$ & \\
\hline
\end{tabular}

The desirable limit of $\mathrm{pH}$ is $6.5-8.5$ for drinking water as per Bureau of Indian Standards (BIS):10500-2012. The $\mathrm{pH}$ values at all the sampling stations were found to be within the desirable limit.

\subsection{2: Alkalinity.}

The alkalinity values analyzed for the water samples at sampling stations 1, 2, 3, 4 and 5 are given below.

Table 4.3: shows the alkalinity values analyzed at five sampling stations for Bhishma lake, Jan 2015 to Apr 2015.

\begin{tabular}{|c|c|c|c|c|c|c|}
\hline Month & $\begin{array}{l}\text { Sampling } \\
\text { station-1 }\end{array}$ & $\begin{array}{l}\text { Sampling } \\
\text { station-2 }\end{array}$ & $\begin{array}{l}\text { Sampling } \\
\text { station-3 }\end{array}$ & $\begin{array}{l}\text { Sampling } \\
\text { station-4 }\end{array}$ & $\begin{array}{l}\text { Sampling } \\
\text { station-5 }\end{array}$ & BIS:10500-2012 \\
\hline $\operatorname{Jan} 27^{\text {th }}$ & 160.00 & 250.00 & 165.00 & 230.00 & 260.00 & DL \\
\hline Feb $11^{\text {th }}$ & 158.00 & 245.21 & 162.00 & 232.00 & 264.00 & \multirow{7}{*}{$200 \mathrm{mg} / \mathrm{L}$} \\
\hline Feb $26^{\text {th }}$ & 162.16 & 251.40 & 163.22 & 235.10 & 262.40 & \\
\hline Mar $13^{\text {th }}$ & 164.28 & 252.36 & 161.80 & 231.60 & 265.00 & \\
\hline $\operatorname{Mar} 27^{\text {th }}$ & 166.00 & 253.70 & 166.43 & 233.55 & 261.60 & \\
\hline Apr $11^{\text {th }}$ & 159.13 & 256.00 & 160.80 & 234.00 & 267.63 & \\
\hline Apr $26^{\text {th }}$ & 157.04 & 254.50 & 167.40 & 230.64 & 260.50 & \\
\hline $\begin{array}{l}\text { Mean } \\
\text { Alkalinity }\end{array}$ & 160.92 & 253.14 & 163.80 & 232.38 & 263.01 & \\
\hline
\end{tabular}

The desirable limit of alkalinity is $200 \mathrm{mg} / \mathrm{L}$ for drinking water as per Bureau of Indian Standards (BIS):10500-2012. Tests were carried out from Jan 2015- April 2015. The average alkalinity values at sampling stations $1,2,3,4$ and 5 are $160.92,253.14,163.80,232.38$ and $263.01 \mathrm{mg} / \mathrm{L}$ respectively. At stations 2,4 and 5 were found to be exceeding the desirable limit for Bhishma lake.

\subsection{3: Dissolved Oxygen (Do).}

The DO values analyzed for the water samples at sampling stations 1, 2, 3, 4 and 5 are given below.

Table 4.4: shows the DO values analyzed at five sampling stations for Bhishma lake, Jan 2015 to Apr 2015.

\begin{tabular}{|c|c|c|c|c|c|c|}
\hline Month & $\begin{array}{l}\text { Sampling } \\
\text { station-1 }\end{array}$ & $\begin{array}{l}\text { Sampling } \\
\text { station-2 }\end{array}$ & $\begin{array}{l}\text { Sampling } \\
\text { station-3 }\end{array}$ & $\begin{array}{l}\text { Sampling } \\
\text { station-4 }\end{array}$ & $\begin{array}{l}\text { Sampling } \\
\text { station-5 }\end{array}$ & $\begin{array}{l}\text { BIS: } \\
10500- \\
2012\end{array}$ \\
\hline $\operatorname{Jan} 27^{\text {th }}$ & 1.86 & 2.89 & 3.10 & 3.56 & 3.84 & \multirow{8}{*}{ NG } \\
\hline Feb1 $11^{\text {th }}$ & 1.83 & 2.88 & 3.15 & 4.0 & 3.65 & \\
\hline Feb $26^{\text {th }}$ & 1.80 & 2.86 & 3.20 & 4.2 & 4.20 & \\
\hline $\operatorname{Mar} 13^{\text {th }}$ & 0.80 & 2.83 & 3.24 & 3.9 & 4.13 & \\
\hline $\operatorname{Mar} 27^{\text {th }}$ & 0.84 & 2.84 & 2.89 & 4.00 & 4.00 & \\
\hline Apr $11^{\text {th }}$ & 0.89 & 2.75 & 2.88 & 4.22 & 3.97 & \\
\hline Apr $26^{\text {th }}$ & 0.90 & 2.60 & 2.80 & 4.10 & 4.10 & \\
\hline Mean DO & 1.27 & 2.80 & 3.03 & 3.90 & 3.97 & \\
\hline
\end{tabular}




\subsection{4: Nitrate.}

sampling stations $1,2,3,4$ and 5 are given below.

The nitrate values analyzed for the water samples at

Table 4.5: Nitrate values analyzed at five sampling stations for Bhishma lake, Jan 2015 to Apr 2015.

\begin{tabular}{|l|l|l|l|l|l|l|}
\hline Month & $\begin{array}{l}\text { Sampling } \\
\text { station-1 }\end{array}$ & $\begin{array}{l}\text { Sampling } \\
\text { station-2 }\end{array}$ & $\begin{array}{l}\text { Sampling } \\
\text { station-3 }\end{array}$ & $\begin{array}{l}\text { Sampling } \\
\text { station-4 }\end{array}$ & $\begin{array}{l}\text { Sampling } \\
\text { station-5 }\end{array}$ & BIS:10500- 2012 \\
\hline $\begin{array}{l}\text { Jan } \\
27^{\text {th }}\end{array}$ & 15.00 & 15.00 & 12.00 & 17.00 & 12.00 & DL \\
\hline $\begin{array}{l}\text { Feb } \\
11^{\text {th }}\end{array}$ & 14.00 & 12.00 & 10.00 & 15.00 & 11.00 & \multirow{2}{*}{$45 \mathrm{mg} / \mathrm{L}$} \\
\hline $\begin{array}{l}\text { Feb } \\
26^{\text {th }}\end{array}$ & 15.00 & 13.00 & 11.00 & 17.00 & 10.00 & \\
\hline $\begin{array}{l}\text { Mar } \\
13^{\text {th }}\end{array}$ & 13.00 & 16.00 & 13.00 & 14.00 & 12.00 & \\
\hline $\begin{array}{l}\text { Mar } \\
27^{\text {th }}\end{array}$ & 12.00 & 14.00 & 12.00 & 13.00 & 13.00 & \\
\hline $\begin{array}{l}\text { Apr } \\
11^{\text {th }}\end{array}$ & 10.00 & 12.00 & 14.00 & 16.00 & 11.00 & \\
\hline $\begin{array}{l}\text { Apr } \\
26^{\text {th }}\end{array}$ & 11.00 & 15.00 & 11.00 & 13.00 & 14.00 & \\
\hline $\begin{array}{l}\text { Mean } \\
\text { Nitrate }\end{array}$ & $\mathbf{1 2 . 8 5}$ & $\mathbf{1 3 . 8 5}$ & $\mathbf{1 1 . 8 2}$ & $\mathbf{1 5 . 0 0}$ & $\mathbf{1 1 . 8 5}$ & \\
\hline
\end{tabular}

It is found that the average values of nitrate for all the sampling stations $1,2,3,4$ and 5 are $12.85,13.85,11.82$, 15.00 and $11.85 \mathrm{mg} / \mathrm{L}$ respectively were found to be within desirable limit. The desirable limit for nitrate is $45 \mathrm{mg} / \mathrm{L}$ for drinking water as per Bureau of Indian Standards (BIS):10500-2012.

\subsection{5: Phosphate.}

The phosphate values analyzed for the water samples at sampling stations 1, 2, 3, 4 and 5 are given below.

Table 4.6: Phosphate values analyzed at five sampling stations for Bhishma lake, Jan 2015 to Apr 2015.

\begin{tabular}{|l|l|l|l|l|l|l|}
\hline Month & $\begin{array}{l}\text { Sampling } \\
\text { station-1 }\end{array}$ & $\begin{array}{l}\text { Sampling } \\
\text { station-2 }\end{array}$ & $\begin{array}{l}\text { Sampling } \\
\text { station-3 }\end{array}$ & $\begin{array}{l}\text { Sampling } \\
\text { station-4 }\end{array}$ & $\begin{array}{l}\text { Sampling } \\
\text { station-5 }\end{array}$ & $\begin{array}{l}\text { BIS:10500- } \\
\mathbf{2 0 1 2}\end{array}$ \\
\hline Jan 2 $7^{\text {th }}$ & 0.024 & 0.028 & 0.026 & 0.030 & 0.029 \\
\hline Feb 11 & 0.022 & 0.026 & 0.024 & 0.028 & 0.026 \\
\hline Feb 26
\end{tabular}

It is found that the average phosphate values for all the sampling stations $1,2,3,4$ and 5 are $0.023,0.025,0.025$, 0.026 and $0.027 \mathrm{mg} / \mathrm{L}$ respectively. These values are significant for leaching of fertilizers and pesticides.

\subsection{6: Biochemical Oxygen Demand (Bod).}

The BOD values analyzed for the water samples at sampling stations 1, 2, 3, 4 and 5 are given below. 
Table 4.7: BOD values analyzed at five sampling stations for Bhishma lake, Jan 2015 to Apr 2015

\begin{tabular}{|l|l|l|l|l|l|l|}
\hline Month & $\begin{array}{l}\text { Sampling } \\
\text { station-1 }\end{array}$ & $\begin{array}{l}\text { Sampling } \\
\text { station-2 }\end{array}$ & $\begin{array}{l}\text { Sampling } \\
\text { station-3 }\end{array}$ & $\begin{array}{l}\text { Sampling } \\
\text { station-4 }\end{array}$ & $\begin{array}{l}\text { Sampling } \\
\text { station-5 }\end{array}$ & $\begin{array}{l}\text { BIS: 10500- } \\
\mathbf{2 0 1 2}\end{array}$ \\
\hline Jan 31 & st & 4.5 & 5.2 & 4.8 & 4.5 & 5.1 \\
\hline Feb 16 & th & 4.1 & 5.0 & 4.6 & 4.3 & 5.0 \\
\hline Mar 2 & nd & 4.3 & 4.8 & 4.4 & 4.2 & 4.8 \\
\hline Mar 16 & 4.0 & 4.6 & 4.9 & 4.4 & 4.6 \\
\hline Mar 30 & 4.2 & 5.1 & 4.5 & 4.6 & 4.4 \\
\hline Apr 14 & 4.1 & 4.9 & 4.7 & 4.7 & 4.4 \\
\hline Apr 30 & 4.6 & 5.2 & 4.5 & 4.8 & 5.3 \\
\hline Mean BOD & $\mathbf{4 . 2 5}$ & $\mathbf{4 . 9 7}$ & $\mathbf{4 . 6 2}$ & $\mathbf{4 . 5 0}$ & $\mathbf{4 . 8 0}$ \\
\hline
\end{tabular}

It is observed that average BOD values at all the five sampling stations 1, 2, 3, 4 and 5 are $4.25,4.97,4.62,4.50$ and $4.80 \mathrm{mg} / \mathrm{L}$ respectively. From the analysis it is clear that average BOD values are high and water is contaminated with organic matter and inorganic pollutants.

\subsubsection{3: Chemical Oxygen Demand (Cod).}

The COD values analyzed for the water samples at sampling stations 1, 2, 3, 4 and 5 are given below.

Table 4.2.8: COD values analyzed at five sampling stations for Bhishma lake, Jan 2015 to Apr 2015.

\begin{tabular}{|l|l|l|l|l|l|l|}
\hline Month & $\begin{array}{l}\text { Sampling } \\
\text { station-1 }\end{array}$ & $\begin{array}{l}\text { Sampling } \\
\text { station-2 }\end{array}$ & $\begin{array}{l}\text { Sampling } \\
\text { station-3 }\end{array}$ & $\begin{array}{l}\text { Sampling } \\
\text { station-4 }\end{array}$ & $\begin{array}{l}\text { Sampling } \\
\text { station-5 }\end{array}$ & BIS:10500-2012 \\
\hline Jan $31^{\text {st }}$ & 10.0 & 11.0 & 12.00 & 10.0 & 13.0 \\
\hline Feb 16 & th & 8.62 & 9.53 & 10.26 & 9.31 & 12.0 \\
\hline Mar 2 & nd & 8.54 & 9.52 & 8.46 & 8.70 & 9.90 \\
\hline Mar 16 & 9.42 & 10.23 & 9.00 & 9.52 & 8.60 \\
\hline Mar 30 & 9.67 & 9.21 & 8.62 & 9.72 & 7.52 & NG \\
\hline Apr 14 & 9.40 & 10.40 & 8.31 & 10.25 & 7.60 \\
\hline Apr 30 & 9.52 & 9.40 & 11.30 & 9.72 & 7.65 \\
\hline Mean COD & $\mathbf{9 . 3 1}$ & $\mathbf{9 . 8 9}$ & $\mathbf{9 . 7 0}$ & $\mathbf{9 . 6 0}$ & $\mathbf{9 . 4 6}$ \\
\hline
\end{tabular}

It is observed that average COD values at all the five sampling stations 1, 2, 3, 4 and 5 are 9.31, 9.89, 9.70, 9.60 and $9.46 \mathrm{mg} / \mathrm{L}$ respectively. These average values of COD indicate the extent of pollution because of organic and inorganic pollutants present in the water.

\section{2: Sewage Quantity Discharging Into Bhishma}

Lake.

Table 4.2.9: Sewage quantity discharging into Bhishma lake. ${ }^{[22]}$

\begin{tabular}{|l|l|l|l|l|}
\hline Months & Jan & Feb & Mar & Apr \\
\hline Sewage quantity in liter/ month & $15,25,440$ & $15,25,520$ & $15,25,405$ & $12,25,612$ \\
\hline Average sewage quantity in liter & \multicolumn{5}{l}{} \\
& $14,50,494$ & & \\
& & & & \\
\end{tabular}

\section{CONCLUSIONS}

Bhishma lake is situated in the Gadag city. Total area of lake is $20,234 \mathrm{~m}^{2}$. Five sampling stations were selected for the water quality analysis. A part of city sewage and domestic waste is entering into lake. Five sewage points are joining the Bhishma lake 1) Karyappa circle, 2) Near Mahatma Gandhi hospital, 3) Hotel Shivani Inn cross, 4) Bellary road idiga maidhan and 5) Dambal naka. 2,542.4 liter of sewage is joining from each point. Per day 50,848 liter of sewage is discharged for four hours into the Bhishma lake. It is a rain fed natural lake and from the analysis it was found that the major problem faced by lake is sewage discharge, waste dumping and other human activities such as washing cloth, animals and vehicles. Water is available throughout the year in the Bhishma lake.

$>\quad$ During the study period of four months from January 2015 to April 2015 the raw sewage sample were collected monthly once and the following parameters were tested such as $\mathrm{pH}$, Chloride, DO, BOD, COD, TDS, Nitrate, Phosphate and Suspended solids. The values obtained for $\mathrm{pH}$ varied from 6.20 to 6.70, Chloride varied from 55.20 to $68.12 \mathrm{mg} / \mathrm{L}$, DO were found to be 0 , BOD varied from 208.32 to 238.72 $\mathrm{mg} / \mathrm{L}$, COD varied from 335.12 to $392.0 \mathrm{mg} / \mathrm{L}$, TDS varied from 580.10 to $648.18 \mathrm{mg} / \mathrm{L}$, Nitrate varied from 54.17 to $58.11 \mathrm{mg} / \mathrm{L}$, Phosphate varied from 6.32 
to $6.33 \mathrm{mg} / \mathrm{L}$ and Total Suspended Solids varied from 192.23 to $273.21 \mathrm{mg} / \mathrm{L}$. From the obtained values the strength of the sewage is considered to be medium.

$>\quad$ The average alkalinity values at sampling stations 1,2 , 3,4 and 5 were $160.92,253.14,163.80,232.38$ and $263.01 \mathrm{mg} / \mathrm{L}$ respectively. At stations 2, 4 and 5 were found to be $253.14,232.38$ and $263.01 \mathrm{mg} / \mathrm{L}$ respectively exceeding the desirable limit of $200 \mathrm{mg} / \mathrm{L}$ for drinking water as per Bureau of Indian Standards (BIS):10500-2012.

$>\quad$ The average chloride values at sampling stations 1,2 , 3,4 and 5 were $152.61,233.25,161.61,232.02$ and $231.74 \mathrm{mg} / \mathrm{L}$ respectively for the Bhishma lake were found to be within the desirable limit of $250 \mathrm{mg} / \mathrm{L}$ for drinking water as per Bureau of Indian Standards (BIS):10500-2012.

$>\quad$ The average DO values at all the five sampling stations $1,2,3,4$ and 5 were $1.27,2.80,3.03,3.90$ and 3.97 $\mathrm{mg} / \mathrm{L}$ respectively. Due to presence of organic and inorganic pollutants in the water DO in the Bhishma lake water is very less. There is no consistency in the average DO values as per the findings.

$>$ From the present study it was found that the average nitrate values at sampling stations $1,2,3,4$ and 5 were $12.85,13.85,11.82,15.00$ and $11.85 \mathrm{mg} / \mathrm{L}$ respectively were found to be within desirable limit. For drinking water as per Bureau of Indian Standards (BIS):105002012 the desirable limit of nitrate is $45 \mathrm{mg} / \mathrm{L}$. These values signify fertilizer leaching.

$>$ It is observed that average BOD values at all the five sampling stations 1, 2, 3, 4 and 5 were 4.25, 4.97, 4.62, 4.50 and $4.80 \mathrm{mg} / \mathrm{L}$ respectively. Due to presence of organic and inorganic pollutants in the Bhishma lake water the BOD values are high. These average values directly signify presence of organic matter and the microbial activities.

$>$ It is observed that average COD values at all the five sampling stations 1, 2, 3, 4 and 5 were 9.31, 9.89, 9.70, 9.60 and $9.46 \mathrm{mg} / \mathrm{L}$ respectively. These average values of COD indicate the presence of non-biodegradable contaminants in the Bhishma lake water.

$>$ From the present study it can be concluded that the Bhishma lake is getting polluted by the entry of raw sewage, so the sewage should be diverted away from the lake or allowed to join the lake after treatment.

$>$ Human activities which directly load the lake with pollutants must be monitored. Waste dump is also contributing for the pollution of the lake so the waste dump should be shifted to a place away from the lake and its watershed areas.

\section{REFERENCES}

[1]. Fareed A Khan and Abid Ali Ansari (2002), "Eutrophication: An Ecological Vision", The Botanical Review, Vol 71(4), pp: 449-482.

[2]. J. Hoorman, T. Hone, T. Sudama and K. P Islam (2008), "Agricultural impacts on lake and stream water quality in Grand lake St. Marys, Western Ohio", Water, Air and Soil Pollution, Vol 193, pp: 309-322.
[3]. Surana R, B.R Subba and K.P Limbu (2011), "Physico-chemical studies on Chimidi lake of Sunsari district during its restoration stage", Journal of Environmental Management, Vol 92, pp: 749-755.

[4]. G.K Khadse (2008), "Qualitative evaluation of Kanhan river and its tributaries flowing over central Indian plateau", Environmental Monitoring and Assessment, Vol 147, pp: 83-92.

[5]. Omkar Singh, S. P. Rai, Vijaykumar, M. K. Sharma (2007), "Water quality and eutrophication status of some lakes of the western Himalayan region (India)", The $12^{\text {th }}$ World Lake Conference, Vol 1, pp: 286-291.

[6]. AKM M Rahaman and Dhia Al Bakri (2008), "Eutophication and algal blooms in inland reservoirs: A Case Study from Australia". Environmental Technology, Vol 3, pp: 1547-1553.

[7]. Jennifer L, Devis and Glenshaw (2008), "Impacts of eutrophication on the safety of drinking and recreational water", Water and Health, Vol 2, pp: 4347.

[8]. William G. Booty, Oskar Resler, Craig M. Crimmon (2003), "Mass balance modeling of priority toxic chemicals decision support system: RateCon model results for lake Ontario and lake Erie", Environmental Modeling and Software, Vol 20, pp: 671-688.

[9]. Rahul Upadhyay, Niladri Dasgupta, Aziz Hasan, S.K. Upadhyay (2011), "Managing water quality of river Yamuna in NCR Delhi", Physics and Chemistry of the Earth, Vol 36, pp: 372-378.

[10]. Ying Zhao, Zhifeng Yang, Yingxia Li (2010), "Investigation of water pollution in Baiyangdian lake, China", Environmental Sciences, Vol 2, pp: 737-748.

[11]. Tang Qiu, Tian Zhi, Wilko Schweers (2012), "Study on environmental risk and economic benifits of rotation systems in farmland of Erhai lake basin", Journal of Integrative Agriculture, Vol 11(6), pp: 1038-1047.

[12]. Li Minghui, Zhang Wen, Xia Yu (2011), "Study on removal efficiencies of pollutant from constructed wetland in aquiculture waste water around Poyang lake", Environmental Sciences, Vol 10, pp: 2444-2448.

[13]. Tirivashe P. Masere, Adelaide Munodawafa, Tavengwa Chitata (2012), "Assessment of human impact on water quality along Manyame River", International Journal of Development and Sustainability, Vol 1, pp: 33-48.

[14]. Sulekh Chandra, Arendra Singh and Praveen Kumar Tomar (2012), "Assessment of water quality values in Porur lake Chennai, Hussain Sagar lake, Hyderabad and Vihar lake Mumbai", Chem Sci Transactions, Vol 1(3), pp: 508-515.

[15]. Muhammad Aqeel Ashraf, Mohd Jamil Maah, Ismail Yusoff and Karamat Mehmood (2010), "Effects of polluted water irrigation on environment and health of people in Jamber, district Kasur, Pakistan", International Journal of Basic and Applied Sciences, Vol 10, pp: 31-38.

[16]. Jin Hong, Xiumei Guo, Dora Marinova and Dingtao Zhao (2008), "Analysis of water pollution and ecosystem health in the Chao lake basin, China", 
Journal of Applied Sciences, Vol 7, pp: 1966-1972.

[17]. J.Hoorman, T. Hone, Sudman Jr, T. Dirksen (2008), "Agricultural impacts on lake and stream water quality in Grand lake St. Marys, Western Ohio", Water Air Soil Pollution, Vol 193, pp: 309-322.

[18]. K. C. Khare and M.S. Jadhav (2008), "Water quality assessment of Katraj lake, Pune: A Case Study", $12^{\text {th }}$ World lake Conference, Vol 1, pp: 292-299.

[19]. The U.P Water Prevention and Control Board No.133/A.R.N/16 Lucknow, May 13, 1976.

[20]. Santosh Kumar Garg (2014), "Sewage disposal and air pollution engineering", Environmental Engineering, Vol 2, pp:56.

[21]. American Public Health Association (APHA), American Water Works Association (AWWA) (1998), "Standard Methods for the Examination of Water and Wastewater", $20^{\text {th }}$ edition, Washington D.C, U.S.A.

[22]. City Municipal Council, Gadag-Betgeri 2011.

[23]. BIS, Indian Standard Drinking Water Specification (2012), "Bureau of Indian Standard". 